\title{
Thermoanaerobacterium aotearoense sp. nov., a Slightly Acidophilic, Anaerobic Thermophile Isolated from Various Hot Springs in New Zealand, and Emendation of the Genus Thermoanaerobacterium
}

\author{
SHU-YING LIU, ${ }^{1}$ FREDERICK A. RAINEY, ${ }^{2}$ HUGH W. MORGAN, ${ }^{3}$ FRANK MAYER, ${ }^{4}$ \\ AND JUERGEN WIEGEL ${ }^{1 *}$ \\ Department of Microbiology and Center for Biological Resource Recovery, University of Georgia, Athens, Georgia \\ 30602 ${ }^{1}$; Deutsche Sammlung von Mikroorganismen und Zellkulturen, D-38124 Braunschweig, Germany ${ }^{2}$; \\ Department of Biological Sciences, University of Waikato, Hamilton, New Zealand ${ }^{3}$; and \\ Institut für Mikrobiologie, Universität Göttingen, D-37077 Göttingen, Germany ${ }^{4}$
}

\begin{abstract}
Six moderately acidophilic, thermophilic bacterial strains with similar properties were isolated from geothermally heated water and sediment samples collected in New Zealand. These Gram stain-negative but Gram type-positive, rod-shaped bacteria formed oval terminal endospores. The cells were peritrichously flagellated and exhibited tumbling motility. At $60^{\circ} \mathrm{C}$ the $\mathrm{pH}$ range for growth was 3.8 to 6.8 , and the optimum $\mathrm{pH}$ was 5.2 when the organisms were grown with xylose. At pH 5.2 the temperature range for growth was 35 to $66^{\circ} \mathrm{C}$, and the optimum temperature was 60 to $63^{\circ} \mathrm{C}$. The fermentation products from glucose or xylose were ethanol, acetate, lactate, $\mathrm{CO}_{2}$, and $\mathrm{H}_{2}$. The DNA G+C content was 34.5 to $35 \mathrm{~mol} \%$. On the basis of properties such as formation of elemental sulfur from thiosulfate, growth at acidic $\mathrm{pH}$ values at elevated temperatures, and the results of a 16S rRNA sequence comparison performed with previously validly published species belonging to the genus Thermoanaerobacterium, we propose that strain JW/SL-NZ613 ${ }^{\mathrm{T}}(\mathrm{T}=$ type strain) and five similar strains isolated from samples collected in New Zealand represent a new species, Thermoanaerobacterium aotearoense. Strain JW/SL-NZ613 ${ }^{\mathrm{T}}$ (= DSM 10170) is the type strain of this species.
\end{abstract}

Recently, acidophilic thermophilic (eu)bacteria and archaea have been studied because of their potential for use in industrial applications which require enzymes that are stable at $\mathrm{pH}$ 5.0 and below and at temperatures above $50^{\circ} \mathrm{C}(19,30)$. The enzymes produced by these bacteria include xylose (glucose) isomerases, which are used in the production of high-fructose corn syrup, and proteases and xylanases, which are used in various other processes. Thermophilic, acidophilic (eu)bacteria have been isolated from a variety of thermobiotic and mesobiotic environments, and most of the isolates belong to the genera Bacillus and Alicyclobacillus (41). One of these organisms is Bacillus tusciae (3), which has an optimum $\mathrm{pH}$ between 4.2 and 4.8. Among the obligate anaerobes, only slightly acidophilic strains have been isolated. Many of these organisms are archaea, and this group includes methanogens, such as Methanococcus igneus (5), Methanococcus jannaschii (11), and Methanothermus sociabilis (15), which have optimum $\mathrm{pH}$ values that range from 5.7 to 6.5 , and glycolytic and sulfurdependent archaea, such as Pyrodictium abyssi (24), Thermofilum pendens (42), and Thermoproteus tenax (43), which have optimum $\mathrm{pH}$ values that range from 5.0 to 5.5 . The anaerobic acidophilic (eu)bacteria include Acetogenium ("Thermoanaerobacter") kivui (17), Clostridium thermopalmarium (32), Moorella thermoautotrophica $(6,38)$, and Thermoanaerobacterium saccharolyticum (16), which have optimum $\mathrm{pH}$ values that range from 5.7 to 6.6 . Extremely acidophilic hyperthermophiles have been isolated from low-pH terrestrial and marine solfataric fields and smoldering coal refuse piles (34). These organisms are irregularly lobed cocci that grow optimally at about $\mathrm{pH} 3.0$. Most of them are aerobes or facultative anaerobes, and they belong to the

${ }^{*}$ Corresponding author. Mailing address: Department of Microbiology, University of Georgia, 215 Biol. Sci., Athens, GA 30602. Phone: (706) 542-2651. Fax: (706) 542-2674. Electronic mail address: jwiegel@ uga.cc.uga.edu. genera Sulfolobus, Metallosphaera, Acidianus, and Desulfurolobus. Stygiolobus azoricus has the lowest optimum $\mathrm{pH}(\mathrm{pH} 2.6)$ among the anaerobes that have been examined (29).

In this paper, we describe a novel, anaerobic, (eu)bacterial, slightly acidophilic thermophile, Thermoanaerobacterium aotearoense sp. nov., which has an optimum $\mathrm{pH}$ for growth of 5.2 and does not grow at $\mathrm{pH} 7.0$ or above; this organism was isolated from four geothermal hot pools in New Zealand.

\section{MATERIALS AND METHODS}

Sample collection. Mixed water and sediment samples were obtained during September 1991 from geothermally heated pools in New Zealand (North Island) (Table 1). These samples were collected by completely filling sterile, $\mathrm{N}_{2}$-gassed $100-\mathrm{ml}$ glass bottles that were closed with black butyl rubber stoppers. Samples with $\mathrm{pH}$ values below 4 were brought to a $\mathrm{pH}$ between 5.0 and 6.0 by adding sodium bicarbonate. If possible, the samples were kept at temperatures between 2 and $10^{\circ} \mathrm{C}$. However, the samples were intermittently exposed to ambient temperatures during transport to a laboratory in Athens, Ga. The reference strains Thermoanaerobacterium thermosulfurigenes $4 \mathrm{~B}^{\mathrm{T}}(\mathrm{T}=$ type strain), Thermoanaerobacterium saccharolyticum $\mathrm{B} 6 \mathrm{~A}-\mathrm{RI}^{\mathrm{T}}$, and Thermoanaerobacterium xylanolyticum LX-11 $1^{\mathrm{T}}$ were obtained from J. G. Zeikus (Michigan Biotechnology Institute, Lansing).

Isolation and culture conditions. The initial enrichment procedure and isolation were carried out anaerobically at $60^{\circ} \mathrm{C}$ by using a medium containing $15 \mathrm{mM}$ citric acid, $9.3 \mathrm{mM} \mathrm{NH}_{4} \mathrm{Cl}, 3.8 \mathrm{mM}\left(\mathrm{NH}_{4}\right)_{2} \mathrm{SO}_{4}, 17 \mathrm{mM} \mathrm{NaCl}, 0.2 \mathrm{mM} \mathrm{MgCl} 2,0.3$ $\mathrm{mM} \mathrm{CaCl}_{2}, 0.5 \mathrm{mM} \mathrm{Na} 2 \mathrm{~S}, 0.5 \mathrm{mM}$ cysteic acid, $5 \mathrm{ml}$ of a trace element solution (10) per liter, $0.5 \mathrm{ml}$ of a vitamin solution (10) per liter, $0.1 \%$ (wt/vol) yeast extract, and $0.5 \%(\mathrm{wt} / \mathrm{vol})$ xylose as a carbon source. Solidified medium contained $2.0 \%$ (wt/vol) agar (Difco Laboratories, Detroit, Mich.). The $\mathrm{pH}$ was adjusted to 4.5 with $1 \mathrm{~N} \mathrm{NaOH}$.

A 2- to $5-\mathrm{g}$ or 2- to $5-\mathrm{ml}$ sample was inoculated into $25 \mathrm{ml}$ of the medium described above, and the resulting preparation was incubated for 3 to 8 days. The enrichment cultures were then serially diluted and used to inoculate agar shake roll tubes containing the solidified medium. The roll tubes were inverted and incubated at $60^{\circ} \mathrm{C}$ for 3 to 8 days until colonies appeared. Colonies were picked, resuspended in fresh liquid medium, and used to inoculate additional serial dilutions that were used for additional agar shake roll tubes. Several rounds of isolating single colonies were performed to ensure the purity of the strains. Microscopic examination was also used to check the purity of the cultures.

Light microscopy and electron microscopy. Light microscopy was performed by using a model PM-I0AD phase-contrast microscope (Olympus Optical Co., Lid., Tokyo, Japan). Transmission electron microscopy was performed by using a model JEM-100 CXII electron microscope (JEOL, Tokyo, Japan). The meth- 
TABLE 1. Comparison of Thermoanaerobacterium aotearoense strains

\begin{tabular}{|c|c|c|c|c|c|c|}
\hline Characteristic & $\begin{array}{c}\text { Strain } \\
\text { JW/SL-NZ613 }\end{array}$ & $\begin{array}{c}\text { Strain } \\
\text { JW/SL-NZ604 }\end{array}$ & $\begin{array}{c}\text { Strain } \\
\text { JW/SL-NZ606 }\end{array}$ & $\begin{array}{c}\text { Strain } \\
\text { JW/SL-NZ611 }\end{array}$ & $\begin{array}{c}\text { Strain } \\
\text { JW/SL-NZ614 }\end{array}$ & $\begin{array}{c}\text { Strain } \\
\text { JW/SL-NZ625 }\end{array}$ \\
\hline Sample source $\mathrm{pH}^{a}$ & $6.5-7.0$ & 2.3 & 2.3 & $5.2-5.6$ & $6.5-7.0$ & 5.5 \\
\hline Sample source temp $\left({ }^{\circ} \mathrm{C}\right)$ & $50-75$ & $92.5-93.5$ & $92.5-93.5$ & 75 & $50-75$ & $50-59$ \\
\hline Cell width $(\mu \mathrm{m})$ & $0.7-0.9$ & $0.8-1.0$ & $0.7-0.8$ & $0.7-0.9$ & $0.7-1.0$ & $0.8-1.0$ \\
\hline Cell length $(\mu \mathrm{m})$ & $2.0-11$ & $2.0-9.0$ & $2.0-8.0$ & $2.0-14.5$ & $2.5-13.0$ & $2.0-10$ \\
\hline Minimum $\mathrm{pH}^{b}$ & $3.8,3.6$ & $3.8,3.6$ & $4.1,3.8$ & $3.8,3.6$ & $3.8,3.6$ & $4.1,3.8$ \\
\hline Maximum $\mathrm{pH}^{b}$ & $6.8,7.0$ & $6.6,6.8$ & $6.8,7.0$ & $6.6,6.8$ & $6.8,7.0$ & $6.6,6.8$ \\
\hline Optimum $\mathrm{pH}$ & 5.2 & 5.2 & 5.2 & 5.5 & 5.2 & 5.5 \\
\hline Minimum temp $\left({ }^{\circ} \mathrm{C}\right)^{b}$ & 35,32 & 35,32 & $36.5,35$ & 35,32 & 35,32 & $36.5,35$ \\
\hline Maximum temp $\left({ }^{\circ} \mathrm{C}\right)^{b}$ & $66,67.5$ & $66,67.5$ & $66,67.5$ & $66,67.5$ & $66,67.5$ & $66,67.5$ \\
\hline Optimum temp $\left({ }^{\circ} \mathrm{C}\right)$ & $60-63$ & 60 & 63 & $60-63$ & $60-63$ & 60 \\
\hline $\mathrm{G}+\mathrm{C}$ content $(\mathrm{mol} \%)$ & 35 & 35 & 35 & 34.5 & 34.5 & 34.5 \\
\hline
\end{tabular}

${ }^{a}$ The sources of the samples from which the organisms were isolated are as follows: strains JW/SL-NZ613 ${ }^{\mathrm{T}}$ and JW/SL-NZ614, Weimangu thermal valley small pools at the Warbrick Terrace; strains JW/SL-NZ604 and JW/SL-NZ606, Roturua-Whaka Rewarewa back entrance; strain JW/SL-NZ611, pool with black sediment at Weimangu thermal area at Lake Rotomahana; strain JW/SL-NZ625, thermal area of Tokaanu at the south end of Lake Taupo.

${ }^{b}$ The values are the closest values tested at which growth was (first value) and was not (second value) observed.

ods of Valentine et al. (35) and Beuscher et al. (2) were used for negative staining. The samples used for ultrathin sectioning were prepared by using uranyl acetate and lead citrate for poststaining as described by Spurr (33). The Gram type was determined by using the lipopolysaccharide-polymyxin B assay described by Wiegel and Quandt (40).

Surface layer (S-layer) structure. Sodium dodecyl sulfate (SDS)-soluble whole-cell extracts of strains JW/SL-NZ613 ${ }^{\mathrm{T}}$ and JW/SL-NZ606 were separated on $10 \%$ slab gels and stained with either Coomassie brilliant blue for proteins or periodic acid-Schiff staining reagent for carbohydrates as described by Messner et al. (22). Micrographs of freeze-etched and metal-shadowed cell preparations were obtained with a Philips model CM100 electron microscope operated at $80 \mathrm{kV}$ as described previously (22).

$\mathrm{pH}$ and temperature ranges for growth. The $\mathrm{pH}$ and temperature ranges for growth were determined by using the medium described above supplemented with $0.5 \%(\mathrm{wt} / \mathrm{vol}) \mathrm{xylose}$ as the main carbon source. The $\mathrm{pH}$ values investigated ranged from 3.5 to 8.5 and were measured at $60^{\circ} \mathrm{C}$ with a model $825-\mathrm{MP} \mathrm{pH}$ meter (Fisher Scientific, Pittsburgh, Pa.) calibrated at $60^{\circ} \mathrm{C}$ and equipped with a combination $\mathrm{pH}$ electrode (Sensor, Staton, Calif.) and a Fisher Scientific temperature probe. The liquid cultures were inoculated $(2 \%, \mathrm{vol} / \mathrm{vol})$ with cells grown at $\mathrm{pH} 5.0$ and were incubated at $60^{\circ} \mathrm{C}$. The $\mathrm{pH}$ was kept constant $( \pm 0.1 \mathrm{pH}$ unit) by periodically adding $0.5 \mathrm{~N} \mathrm{NaOH}$. The minimum $\mathrm{pH}$, optimum $\mathrm{pH}$, and maximum $\mathrm{pH}$ for strain JW/SL-NZ613 ${ }^{\mathrm{T}}$ were corroborated by the results obtained when the organism was grown in a $100-\mathrm{ml} \mathrm{pH-and} \mathrm{temperature-con-}$ trolled fermentor (Glass Shop, University of Georgia). A temperature gradient incubator (Scientific Industries, Inc., Bohemia, N.Y.) set so that the temperature ranged from 32 to $71.1^{\circ} \mathrm{C}$ was used to determine the temperature range for growth. The cultures were inoculated $(2 \%, \mathrm{vol} / \mathrm{vol})$ with cells grown at $60^{\circ} \mathrm{C}$ and were incubated at the optimum $\mathrm{pH}, 5.2$.

Substrate utilization. The substrates utilized were determined by using Hungate tubes containing $10 \mathrm{ml}$ of the medium (pH 5.2) the described above except that the concentration of yeast extract was $0.055 \%(\mathrm{wt} / \mathrm{vol})$ and test substrates at concentrations of 0.3 to $1 \%$ (wt/vol) were used instead of xylose. The tubes were inoculated $(2 \%, \mathrm{vol} / \mathrm{vol})$ with cells from an exponentially growing culture and were incubated at $60^{\circ} \mathrm{C}$. Changes in optical density and $\mathrm{pH}$ were monitored. Cultures that exhibited increases in optical density at $600 \mathrm{~nm}$ of 0.1 optical density unit or more that were accompanied by a decrease in $\mathrm{pH}$ compared with the control cultures were considered positive for substrate utilization. The control (final optical density at $600 \mathrm{~nm},<0.05$ ) did not contain a test substrate.

Fermentation products. The fermentation products were analyzed by using the medium described above containing $0.5 \%$ (wt/vol) glucose or $0.5 \%(\mathrm{wt} / \mathrm{vol})$ xylose. The cultures were incubated at $\mathrm{pH} 5.0$ and $60^{\circ} \mathrm{C}$. Volatile and nonvolatile fatty acids were analyzed by gas chromatography by using a model $5880 \mathrm{~A}$ gas chromatograph (Hewlett-Packard, Palo Alto, Calif.) equipped with a Chromosorb WAW $10 \%$ SP-100 glass column (Supelco, Inc., Bellefonte, Pa.) and a flame ionization detector (39). Production of $\mathrm{H}_{2}$ and $\mathrm{CO}_{2}$ was analyzed by gas chromatography by using a chromatograph (Varian, Walnut Creek, Calif.) equipped with a Porapak Q 80/100-mesh column (Supelco) and a thermal conductivity detector (18). Glucose and acetate were analyzed by using enzymatic assay kits (catalog no. 139106 and 148261, respectively; Boehringer GmbH, Mannheim, Germany).

Protein profiles. For the total soluble cell protein pattern analysis, 20-ml portions of late-exponential-phase cultures grown in the medium described above containing $0.5 \%$ xylose as the substrate were harvested by centrifugation at $6,000 \times g$ for $10 \mathrm{~min}$. The cells were washed with $10 \mathrm{mM}$ Tris- $1 \mathrm{mM}$ EDTA buffer ( $\mathrm{pH} 6.8$ ), suspended in $0.3 \mathrm{ml}$ of the same buffer, and disrupted by two passages through a chilled $\left(4^{\circ} \mathrm{C}\right)$ French pressure cell (SLM AMINCO, Urbana, IIl.) at $1,265 \mathrm{~kg} / \mathrm{cm}^{2}\left(18,000 \mathrm{lb} / \mathrm{in}^{2}\right)$. The cell debris was removed by centrifugation at $15,000 \times \mathrm{g}$ for $15 \mathrm{~min}$ at $4^{\circ} \mathrm{C}$, and the protein concentration of the supernatant was determined by the method of Bradford (4). Samples containing
$60 \mu \mathrm{g}$ of protein from each strain were analyzed by SDS-polyacrylamide gel electrophoresis (PAGE) with $12 \%$ acrylamide in the separation gel as described by Laemmli (14). Protein bands were visualized by staining with Coomassie brilliant blue R-250 and molecular masses were estimated by comparison by using a low-molecular-weight electrophoresis calibration kit (Pharmacia, Piscataway, N.J.) as the standard.

DNA isolation and determination of $\mathbf{G}+\mathrm{C}$ content. DNA was isolated from cells in the exponential growth phase by the method of Ausubel et al. (1) by using $\mathrm{CsCl}$ gradient ultracentrifugation. The DNA was digested enzymatically, and the guanine-plus-cytosine $(\mathrm{G}+\mathrm{C})$ content was determined by separating the nucleosides by high-performance liquid chromatography as described by Whitman et al. (36) and Mesbah et al. (21).

$16 \mathrm{~S}$ rRNA sequence analysis. Genomic DNA was isolated, and the $16 \mathrm{~S}$ ribosomal DNA (rDNA) was amplified as described previously (25). The sequences of PCR products were determined by using a Taq DyeDeoxy terminator cycle sequencing kit (Applied Biosystems, Foster City, Calif.) as recommended by the manufacturer. Purified sequence reaction mixtures were electrophoresed by using an Applied Biosystems model 373A DNA sequencer. The 16S rDNA sequences of strains JW/SL-NZ613 ${ }^{\mathrm{T}}$, JW/SL-NZ604, JW/SL-NZ606, JW/SLNZ611, JW/SL-NZ614, and JW/SL-NZ625 were aligned manually with previously published $16 \mathrm{~S}$ rDNA sequences of representatives of the genus Clostridium and related taxa. The method of Jukes and Cantor (12) was used to calculate the evolutionary distances from which a phylogenetic dendrogram was reconstructed by using the algorithm of De Soete (7).

Cell wall peptidoglycan structure analysis. Cell walls were prepared and peptidoglycan structure was determined by the methods described by Schleifer and Kandler (28). Amino acids and peptides were separated and characterized by thin-layer chromatography on cellulose sheets.

Nucleotide sequence accession number. The 16S rDNA sequence of strain JW/SL-NZ613 ${ }^{\mathrm{T}}$ has been deposited in the EMBL database under accession number X93359.

\section{RESULTS AND DISCUSSION}

Isolation. To obtain organisms which might harbor a xylose (glucose) isomerase with good activity at $\mathrm{pH}$ values below 6.0 , we used enrichment media that had a $\mathrm{pH}$ between 3.0 and 6.0 (for details see Materials and Methods) and contained $0.5 \%$ (wt/vol) xylose as the main carbon source. More than 100 strains that exhibited xylose isomerase activity at $\mathrm{pH}$ values below 6.5 were isolated from samples obtained from various geothermally heated pools in Iceland, Baja California (Mexico), Mono Lake (United States), Yellowstone National Park (United States), and New Zealand, as well as from anthropogenic sources with elevated temperatures, such as manure and compost samples collected in the vicinity of Athens, Ga. Subsequent studies revealed that some of the isolates obtained from New Zealand samples differed from the other isolates. Six strains were obtained from samples collected from pools in New Zealand which had slightly acidic to near-neutral $\mathrm{pH}$ values (Table 1). The highest measured temperatures in the pools ranged from 59 to $93.5^{\circ} \mathrm{C}$. However, the samples which we used were composite samples obtained from various points in pools that also exhibited lower temperatures. Most of the isolates contained a xylose isomerase that exhibited good ac- 

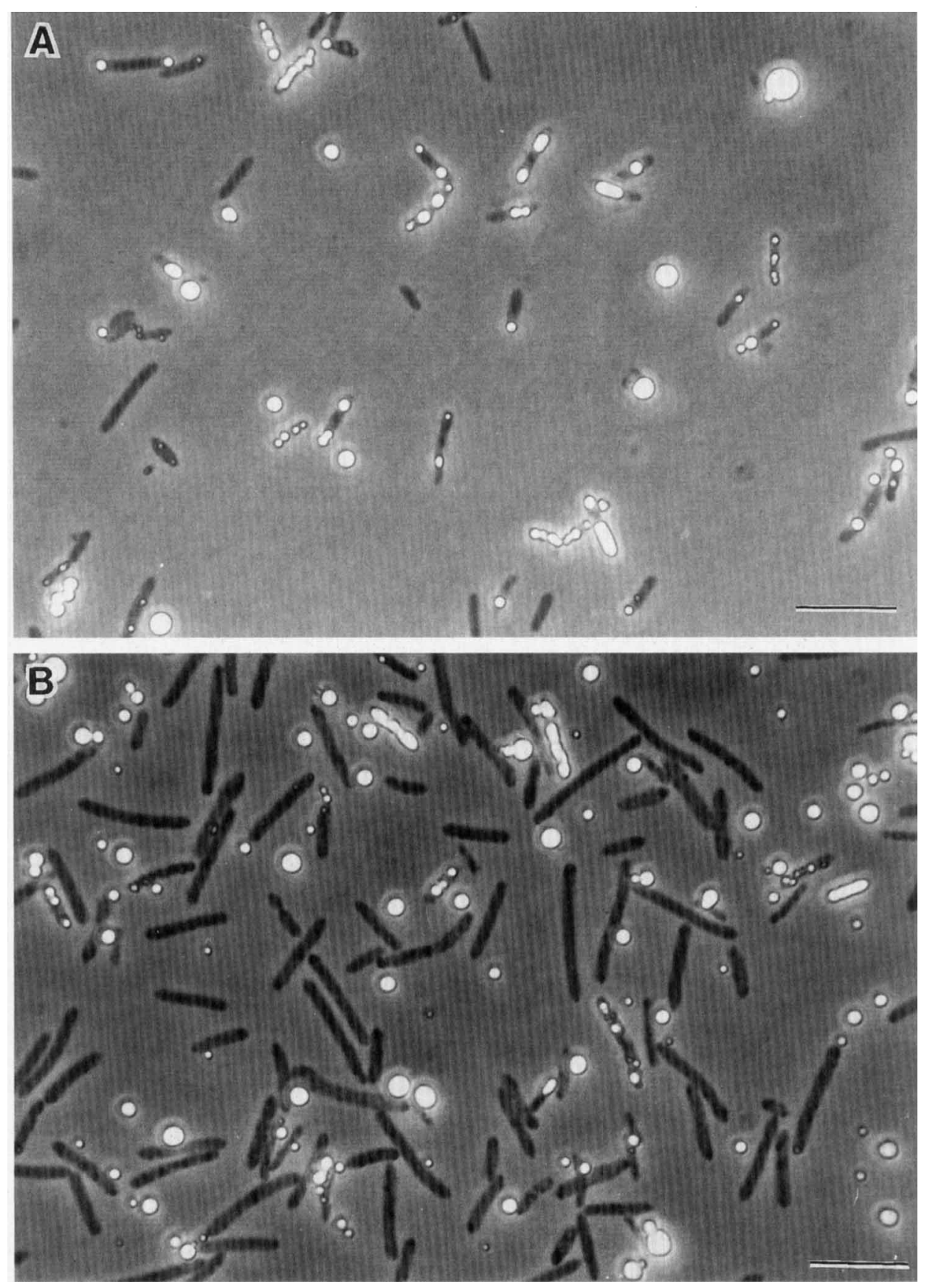

FIG. 1. Phase-contrast photomicrographs of Thermoanaerobacterium aotearoense grown on medium (pH 5.5) containing $0.5 \%$ xylose, $0.1 \%$ yeast extract, and $20 \mathrm{mM}$ $\mathrm{Na}_{2} \mathrm{~S}_{2} \mathrm{O}_{3}$ at $60^{\circ} \mathrm{C}$, showing the accumulation of sulfur in the cells and medium. The cells of strain JW/SL-NZ613 ${ }^{\mathrm{T}}(\mathrm{A})$ and JW/SL-NZ614 (B) were in the late-exponential growth phase. Notice that some cells accumulated sulfur, whereas others did not. Bars $=10 \mu \mathrm{m}$.

tivity at $\mathrm{pH} 4.5$ to 6.5 ; the only exception was strain JW/SLNZ611, which exhibited no detectable activity at $\mathrm{pH} 6.5$ and below (data not shown).

Maintenance. Cultures survived for up to 3 months in liquid medium at room temperature. Liquid cultures that were mixed with anaerobic sterile glycerol at a $1: 1$ ratio and stored at $-70^{\circ} \mathrm{C}$ remained viable for at least 3.5 years (the longest time tested).

Colony and cell morphology. The colonies of all six new isolates were creamy white and translucent. On the surface of the agar, the colonies were circular to slightly irregular and had diameters of about $2 \mathrm{~mm}$; the colonies inside the agar were lens shaped. The cells were rod shaped in all growth phases both in liquid cultures and in solid cultures. The rods ranged from 2 to $14.5 \mu \mathrm{m}$ long and from 0.7 to $1.0 \mu \mathrm{m}$ wide (Table 1). The average length of the cells was longer in the stationary phase than in the exponential growth phase. The cells were peritrichous and exhibited tumbling motility; however, no directed swimming movement was observed. When the organisms were grown with thiosulfate, elemental sulfur was deposited in the cells and was also found in the medium. Electron microscopy unequivocally revealed that sulfur droplets were deposited in the cytoplasm of the cells and were surrounded by a membrane-like hull, but such droplets were not observed between the cytoplasmic membrane and cell wall or outside on 

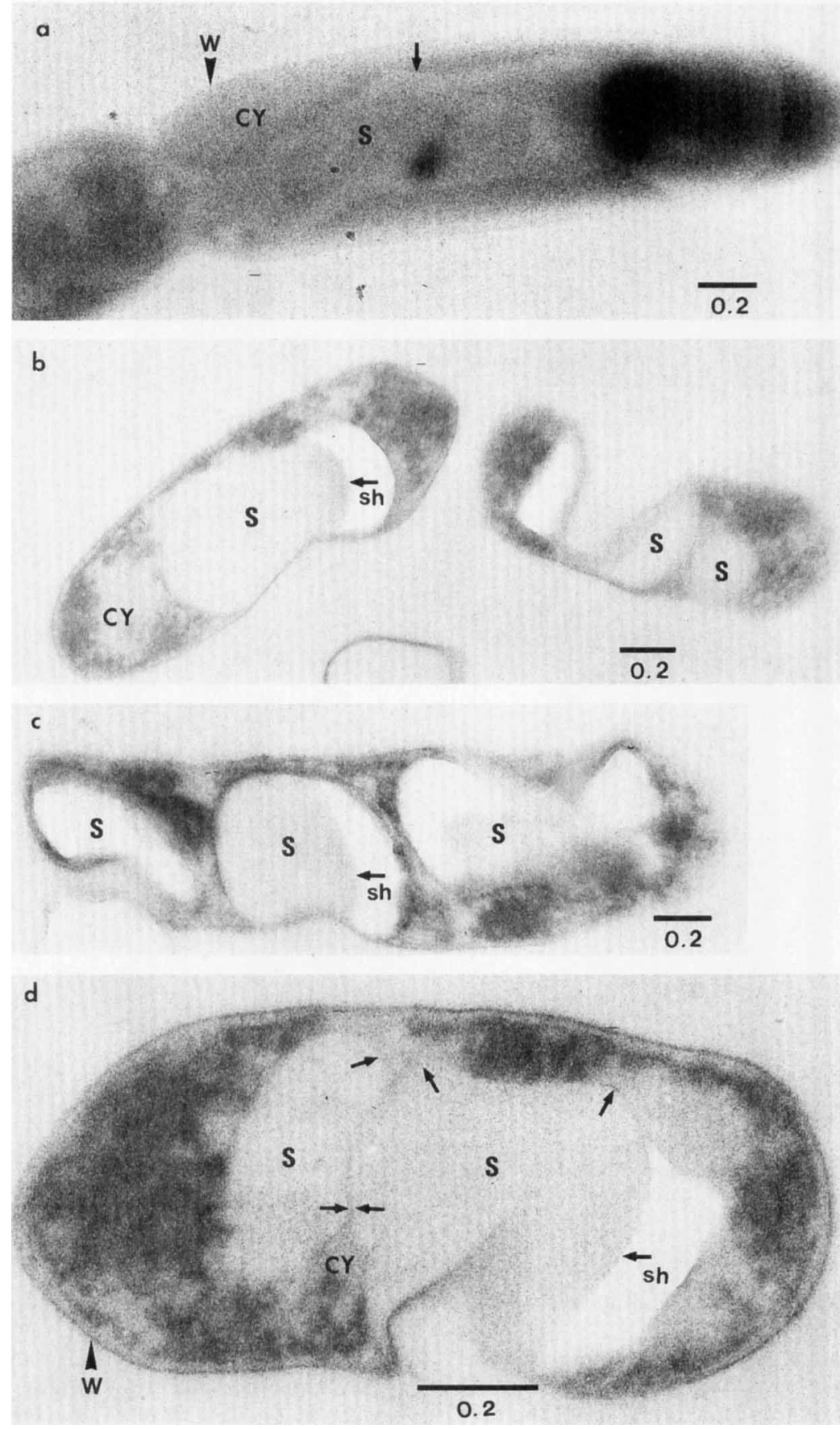

FIG. 2. Strain JW/SL-NZ613 ${ }^{\mathrm{T}}$ grown on medium (pH 5.5) containing $0.5 \%$ xylose, $0.1 \%$ yeast extract, and $20 \mathrm{mM} \mathrm{Na}_{2} \mathrm{~S}_{2} \mathrm{O}_{3}$ at $60^{\circ} \mathrm{C}$, showing the deposition of elemental sulfur droplets inside the cell. Negative staining with neutralized $2 \%(\mathrm{wt} / \mathrm{vol})$ phosphotungstic acid (a) and ultrathin sections (b through d) prepared from chemically fixed, resin-embedded samples. CY, cytoplasm; S, sulfur droplet; sh, shrinkage; W, cell wall. Bar, $2 \mu \mathrm{m}$. (a) Cell in the state of division. Surrounded by cytoplasm, an elongated sulfur droplet is visible that is enclosed by an envelope (arrow). The sulfur inclusion is extended nearly through the entire cell. (b and c) Sections of cells containing one (panel b, left), two (panel b, right), or three (c) sulfur droplets surrounded by cytoplasm. The envelope of the sulfur droplet is in one area of the left cell situated close to the cytoplasmic membrane. The shrinkage in the left cell is due to preparation for electron microscopy, whereas the right cell is collapsed due to partial removal of the contents of the sulfur droplet. (d) As for panel b, but showing the thin envelope (arrows) enclosing the sulfur droplets; the envelopes of neighboring droplets appear to touch each other.

the cell wall (Fig. 1 and 2). However, we performed no additional experiments to determine whether the organisms also catalyzed the formation of sulfur from thiosulfate outside the cells as was indicated by light microscopy or whether the sulfur droplets in the medium originated only from lysed cells.

Sporulation. In general, in both liquid and solidified agar media, 5 to $15 \%$ of the cells sporulated and formed terminal spores in slightly swollen sporangia. Approximately $50 \%$ of the strain JW/SL-NZ611 cells sporulated. The spores were oval, 2.8 to $2.9 \mu \mathrm{m}$ long, and 1.4 to $2.1 \mu \mathrm{m}$ in diameter. Formation of spores usually occurred during the late exponential or early stationary phase. An electron micrograph of ultrathin sections 


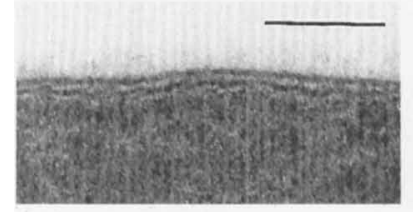

A
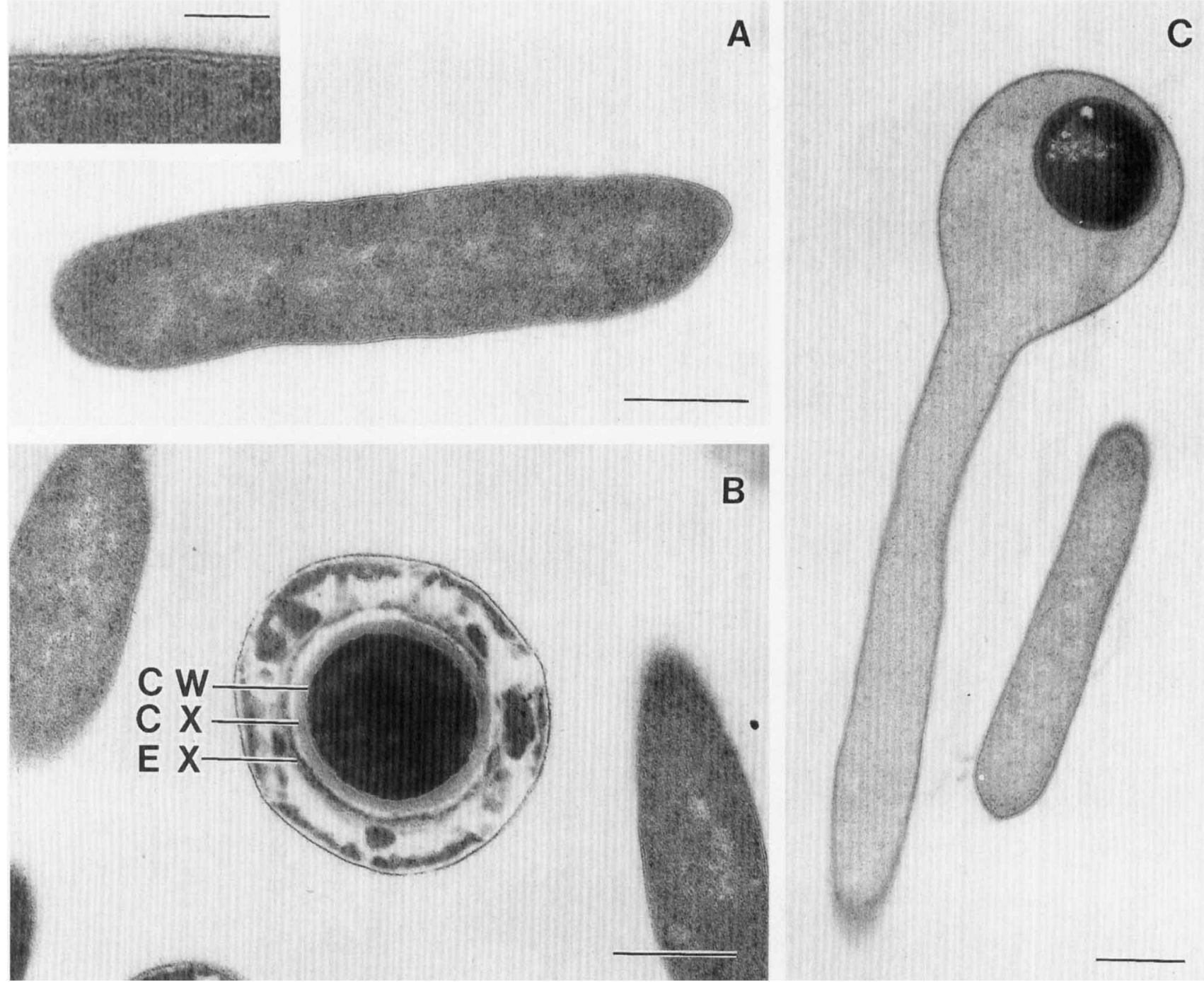

FIG. 3. Electron micrographs of ultrathin sections of ultrathin sections of Thermoanaerobacterium aotearoense. (A) Strain JW/SL-NZ613 ${ }^{\mathrm{T}}$ cell in the exponential growth phase, showing the morphology and Gram type-positive cell wall (Inset). (B and C) Strain JW/SL-NZ611 (B) and JW/SL-NZ613 ${ }^{\mathrm{T}}$ (C) cells in the stationary growth phase, showing endospore formation and mature endospores. $\mathrm{CW}$, cell wall; $\mathrm{CX}$, cortex; EX, exosporium. (A through $\mathrm{C}$ ) Bars $=500 \mathrm{~nm}$. (Inset) Bar $=100 \mathrm{~nm}$.

revealed that the fully developed spores had a typical endospore structure (Fig. 3B and C).

Gram stain reaction, Gram type, and cell wall analysis. The Gram stain reaction was negative, regardless of the growth phase; however, the results of a test for formation of the lipopolysaccharide-polymyxin $\mathrm{B}$ complex gave no indication that lipopolysaccharide was present. Thus, the organisms can be considered Gram type positive $(37,40)$. This cell wall type was also indicated by photomicrographs of ultrathin sections (Fig. 3A). Furthermore, our peptidoglycan structure analysis revealed that strains JW/SL-NZ613 ${ }^{\mathrm{T}}$ and JW/SL-NZ611 had cell wall type A1 $\gamma$ ( $m$-diaminopimelic acid direct), a cell wall type shared by all previously described Thermoanaerobacterium species.

S-layer structure. The cells of strains JW/SL-NZ613 ${ }^{\mathrm{T}}$ and JW/SL-NZ606 were completely covered with hexagonal Slayer lattices (Fig. 4). Although the S-layer lattices of these two strains were clearly visible in freeze-etched preparations, the proteins appeared rather faint on the SDS-PAGE gel or could not be stained at all (data not shown). We know from previously published data that sometimes an S-layer lattice appears rather faint (for a review see references 23 and 31). A recently described explanation for this phenomenon is the amylase which is anchored to the outer leaflet of the S-layer of Bacillus stearothermophilus DSM 2358 (9); the Slayer lattice of this strain becomes clearly visible only after the enzyme is removed by treatment with guanidine hydrochloride.

Physiological and biochemical characterization. All six strains required anoxic conditions for growth. Growth did not occur in oxidized medium, as indicated by the pink color of resazurin. The temperature range for growth of JW/SL-NZ613 ${ }^{\mathrm{T}}$ at pH 5.2 was about 35 to $66^{\circ} \mathrm{C}$, and the optimum temperature was 60 to $63^{\circ} \mathrm{C}$ (Fig. 5A). The pH range for growth at $60^{\circ} \mathrm{C}$ was about $\mathrm{pH} 3.8$ to 6.8 , and the optimum $\mathrm{pH}$ was $\mathrm{pH} 5.2$ (Fig. $5 \mathrm{~B}$ ). The $\mathrm{pH}$ and temperature ranges for growth of all of the isolates are shown in Table 1.

No dissimilatory sulfate reduction activity was detected when strains JW/SL-NZ613 ${ }^{\mathrm{T}}$ and JW/SL-NZ611 were grown in the presence of sulfate with glucose, acetate, or lactate as an 


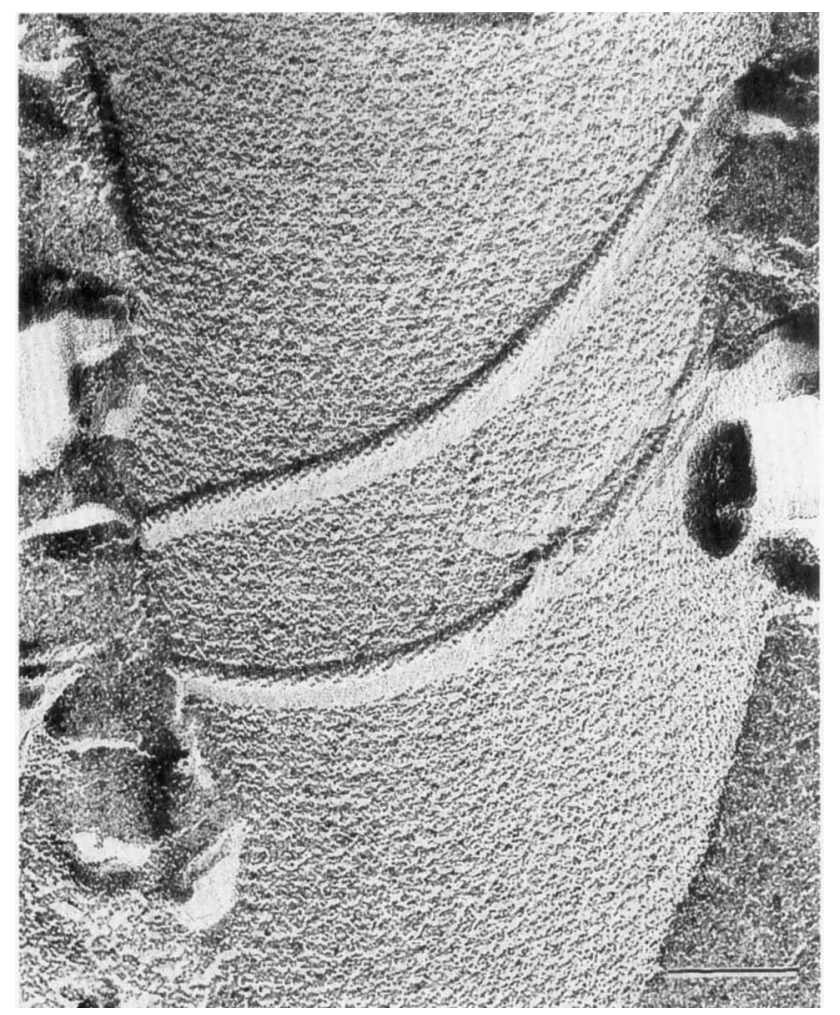

FIG. 4. Electron micrograph of a freeze-etched preparation of intact Thermoanaerobacterium aotearoense JW/SL-NZ613 ${ }^{\mathrm{T}}$ cells, showing the hexagonal lattice of the S-layer and flagella. Bar $=100 \mathrm{~nm}$.

electron donor. The DNA G+C contents of the six isolates ranged from 34.5 to $35 \mathrm{~mol} \%$ (Table 1 ).

When the An-Ident System (API Analytab Products, Plainview, N.Y.) was used, positive results were obtained at $50^{\circ} \mathrm{C}$ for all strains for the following reactions: $\alpha$-arabinosidase, $\beta$-glucosidase, indoxylacetate hydrolysis, histidine aminopeptidase, phenylalanine aminopeptidase, and glycine aminopeptidase. The following reactions were negative for all strains: ammonia production from arginine, indole production, $\mathrm{N}$-acetylglucosaminidase, leucine aminopeptidase, proline aminopeptidase, tyrosine aminopeptidase, tyrosine aminopeptidase, arginine aminopeptidase, alanine aminopeptidase, $\alpha$-glucosidase, $\alpha$-fucosidase, phosphatase, pyroglutamic acid arylamidase, catalase, $\alpha$-galactosidase, and $\beta$-galactosidase.

Substrate utilization and fermentation products. The substrates utilized in the presence of $0.055 \%$ (wt/vol) yeast extract included L-arabinose, galactose, cellobiose, glucose, mannose, fructose, lactose, sucrose, xylose, maltose, starch, rhamnose, pectin, xylan, $N$-acetylglucosamine, and salicin. In addition, some strains utilized ribose (strains JW/SL-NZ613 ${ }^{\mathrm{T}}$, JW/SLNZ606, and JW/SL-NZ614) and raffinose (strains JW/SL$\mathrm{NZ613}^{\mathrm{T}}$, JW/SL-NZ606, JW/SL-NZ611, and JW/SL-NZ614). The substrates that were not utilized included D-arabinose, cellulose, glycerol, methanol, ethanol, xylitol, tartrate, succinate, pyruvate, malonic acid, glucuronic acid, polygalacturonic acid, and $\mathrm{H}_{2}-\mathrm{CO}_{2}$. The fermentation products produced by JW/SL$\mathrm{NZ} 13^{\mathrm{T}}$ and JW/SL-NZ611 from glucose or xylose in the presence of $0.1 \%$ yeast extract were ethanol, acetate, lactate, $\mathrm{CO}_{2}$, and $\mathrm{H}_{2}$; the ratios of these products were about $1: 1: 0.5: 2: 2$ (glucose) and 1:1:0.1:2:2 (xylose).

$16 S$ rRNA sequence analysis and protein profile. We determined the almost complete $16 \mathrm{~S}$ rDNA sequences ( $>95 \%$ of the $E$. coli sequence) of strains JW/SL-NZ613 ${ }^{\mathrm{T}}$, JW/SL-NZ611, and JW/SL-NZ614 and partial 16S rDNA sequences of the $5^{\prime}$ end of the gene (approximately 500 to 800 nucleotides) of the other strains. Our analysis revealed that all of the strains have very similar sequences (Table 2 and Fig. 6); however, these sequences differ from all four previously described Thermoanaerobacterium sequences. Cellular protein patterns obtained by gel electrophoresis are useful for differentiating species and have been shown to be correlated with levels of DNA-DNA homology (8). The cellular protein patterns of our six isolates and three previously described Thermoanaerobacterium species are shown in Fig. 7. The band patterns of the six new isolates are similar and differ significantly from the Thermoanaerobacterium saccharolyticum, Thermoanaerobacterium thermosulfurigenes, and Thermoanaerobacterium xylanolyticum patterns. Differences in the protein profiles and 16S rRNA sequences, as well as small differences in cell morphology, growth range, $\mathrm{G}+\mathrm{C}$ content, and substrate utilization patterns (Tables 1 and 3), suggested that the six new isolates were different strains of the same species and were different from the previously described Thermoanaerobacterium species. On the basis of the 16S rRNA sequences, the physiological data, the $\mathrm{pH}$ and temperature ranges for growth, and the total soluble protein profiles, we concluded that the new isolates belong to a new Thermoanaerobacterium species, for which we propose the name Thermoanaer-
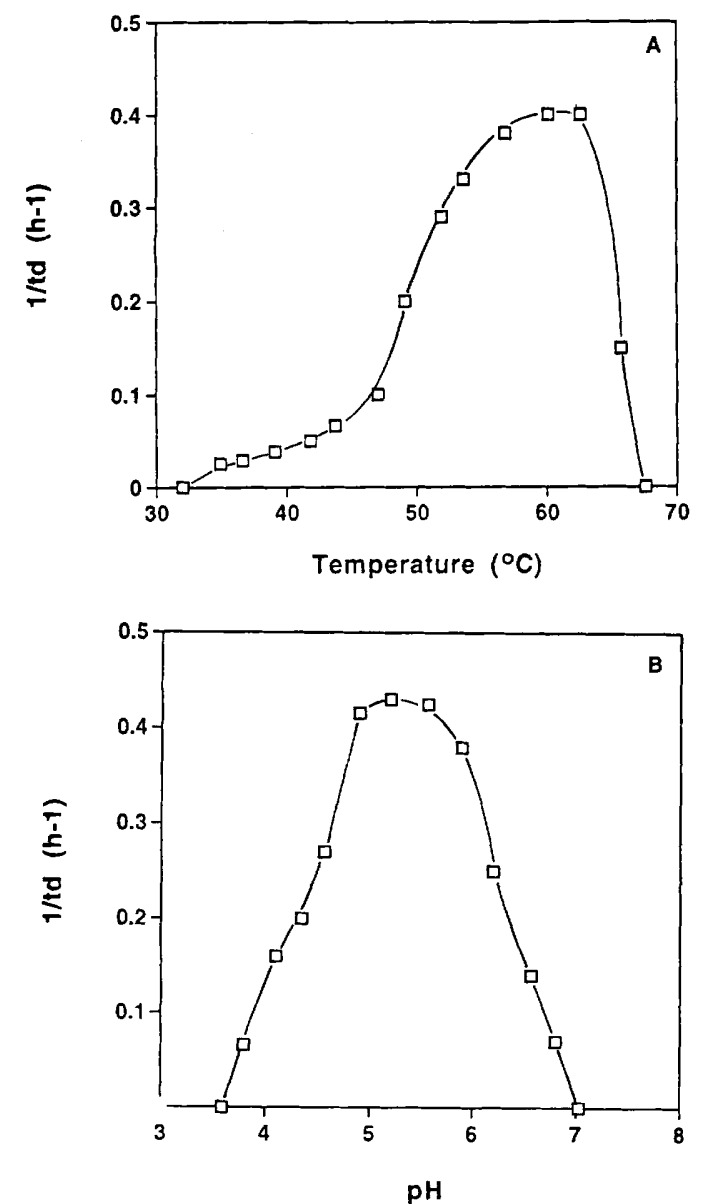

FIG. 5. Growth of Thermoanaerobacterium aotearoense JW/SL-NZ613 ${ }^{\mathrm{T}}$ at various incubation temperatures at $\mathrm{pH} 5.2$ (A) and at various $\mathrm{pH}$ values at $60^{\circ} \mathrm{C}$ (B). td, doubling time. 
TABLE 2. Levels of 16S rDNA similarity for strains JW/SL-NZ613 ${ }^{\mathrm{T}}$, JW/SL-NZ614, and JW/SL-NZ611 and related taxa

\begin{tabular}{|c|c|c|c|c|c|c|c|c|c|c|c|c|c|}
\hline \multirow[b]{2}{*}{ Organism } & \multicolumn{13}{|c|}{$\% 16 \mathrm{~S}$ rDNA similarity } \\
\hline & 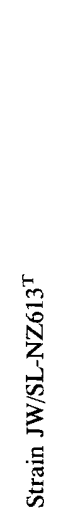 & 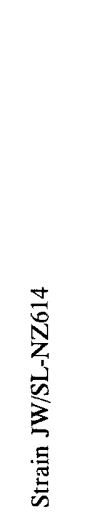 & 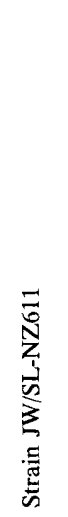 & 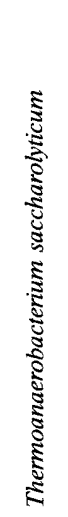 & 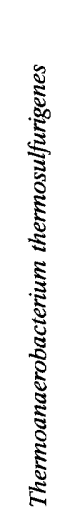 & 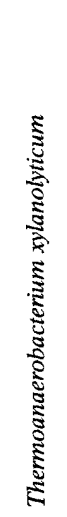 & 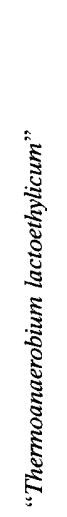 & 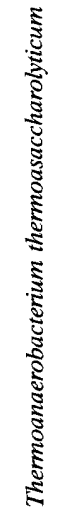 & 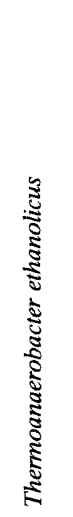 & 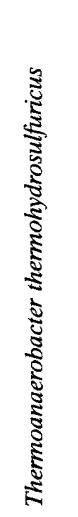 & 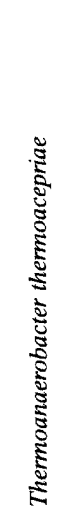 & 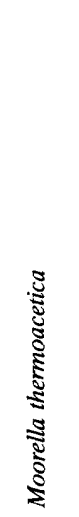 & 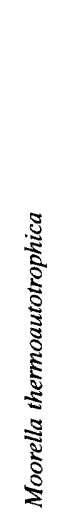 \\
\hline Strain JW/SL-NZ614 & 99.9 & & & & & & & & & & & & \\
\hline Strain JW/SL-NZ611 & 99.9 & 100.0 & & & & & & & & & & & \\
\hline Thermoanaerobacterium saccharolyticum & 98.3 & 98.2 & 98.2 & & & & & & & & & & \\
\hline Thermoanaerobacterium thermosulfurigenes & 98.3 & 98.2 & 98.2 & 98.3 & & & & & & & & & \\
\hline Thermoanaerobacterium xylanolyticum & 98.1 & 98.0 & 98.0 & 98.3 & 99.3 & & & & & & & & \\
\hline "Thermoanaerobium lactoethylicum" & 97.8 & 97.7 & 97.7 & 98.2 & 98.8 & 98.5 & & & & & & & \\
\hline Thermoanaerobacterium thermosaccharolyticum & 98.3 & 98.2 & 98.2 & 97.5 & 97.7 & 97.5 & 97.5 & & & & & & \\
\hline Thermoanaerobacter ethanolicus & 86.3 & 86.2 & 86.2 & 86.2 & 87.1 & 86.8 & 86.8 & 86.3 & & & & & \\
\hline Thermoanaerobacter thermohydrosulfuricus & 86.7 & 86.6 & 86.6 & 86.7 & 87.5 & 87.3 & 87.2 & 86.7 & 98.1 & & & & \\
\hline Thermoanaerobacter thermocopriae & 85.6 & 85.5 & 85.5 & 85.5 & 86.0 & 85.7 & 86.0 & 85.8 & 93.7 & 93.7 & & & \\
\hline Moorella thermoacetica & 86.7 & 86.6 & 86.6 & 86.7 & 87.0 & 86.7 & 87.0 & 87.0 & 87.5 & 87.8 & 87.4 & & \\
\hline Moorella thermoautotrophica & 86.7 & 86.6 & 86.6 & 86.7 & 86.9 & 86.6 & 87.1 & 86.9 & 87.2 & 87.4 & 87.0 & 99.3 & \\
\hline Caldicellulosiruptor saccharolyticum & 82.9 & 82.8 & 82.8 & 82.7 & 83.2 & 82.7 & 83.2 & 83.2 & 83.7 & 83.6 & 84.9 & 83.5 & 83.5 \\
\hline
\end{tabular}

obacterium aotearoense. This species now contains only strains that were isolated from geothermally heated sources in New Zealand.

Differentiation of Thermoanaerobacterium aotearoense from phylogenetically related organisms. Although the organisms which we studied do differ in some physiological characteristics (Thermoanaerobacterium aotearoense has the lowest optimum

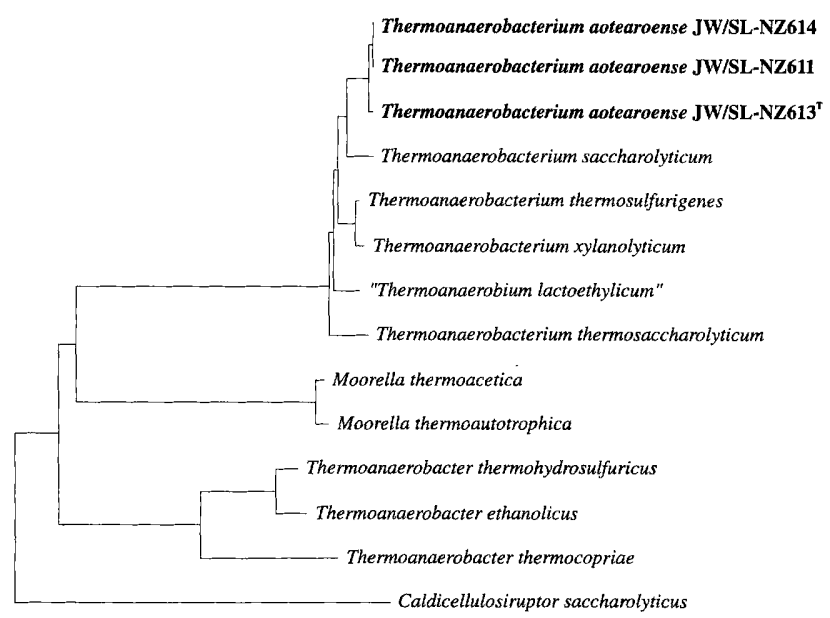

FIG. 6. Phylogenetic dendrogram showing the positions of three Thermoanaerobacterium aotearoense strains within the radiation of the genus Thermoanaerobacterium and related taxa. Bar $=5$ nucleotide substitutions per 100 nucleotides.
$\mathrm{pH}$ and does not grow at $\mathrm{pH} 7.0$ ) (Table 3), the major characteristics used for differentiation are the differences in the whole-cell protein patterns, the clustering of these New Zealand strains, and the separation of these strains from the previously described species on the $16 \mathrm{~S}$ rRNA-based phylogenetic tree.

A comparison of the $16 \mathrm{~S}$ rDNA sequences determined in this study indicated that all of the new strains are closely related. Our phylogenetic analysis in which almost complete sequences were used placed strains JW/SL-NZ613 ${ }^{\mathrm{T}}$, JW/SLNZ611, and JW/SL-NZ614 in the cluster that includes the genus Thermoanaerobacterium (Fig. 6). The levels of $16 \mathrm{~S}$ rDNA sequence similarity between strain JW/SL-NZ613 ${ }^{\mathrm{T}}$ and the species assigned to the genus Thermoanaerobacterium previously range from 97.8 to $98.3 \%$ (Table 2); thus, the sequence data support the establishment of a new species. The highest level of sequence similarity found $(98.3 \%)$ is the level of sequence similarity with Thermoanaerobacterium saccharolyticum.

Our 16S rDNA sequence analysis clearly revealed that the strains which we analyzed fall within the radiation of the cluster that is made up by the strains of the genus Thermoanaerobacterium. The distinct phylogenetic position of this genus has been demonstrated previously by $100 \%$ recoverability in bootstrap analyses $(7,26)$. The new isolates represent a distinct branch within the Thermoanaerobacterium cluster.

Emendation of the description of the genus Thermoanaerobacterium. The genus Thermoanaerobacterium was validly described by Lee et al. (16), who found that sulfur droplets could not be detected inside the cells. We found that the sulfur droplets formed during growth in the presence of thiosulfate $(20 \mathrm{mM})$ are located in the cytoplasm of Thermoanaer- 


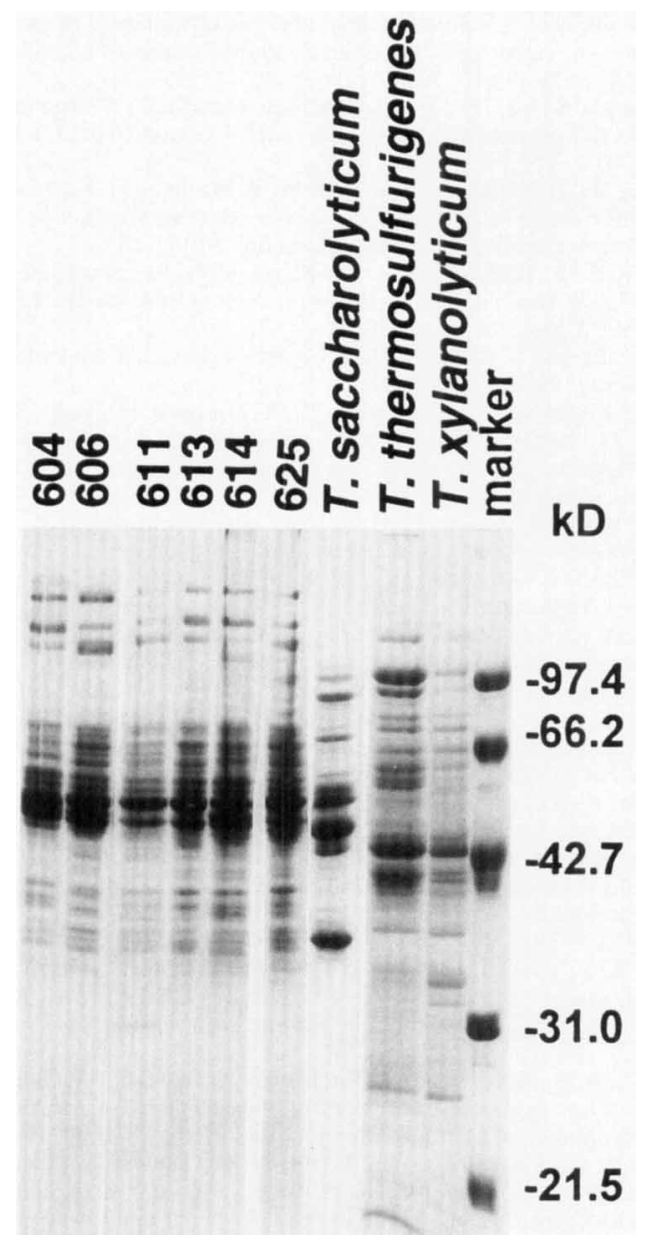

FIG. 7. Electrophoretic comparison of cellular proteins $(60 \mu \mathrm{g}$ of protein per lane) from six strains of Thermoanaerobacterium aotearoense and the type strains of three other Thermoanaerobacterium species. The lanes contained (from left to right) Thermoanaerobacterium aotearoense JW/SL-NZ604, Thermoanaerobacterium aotearoense JW/SL-NZ606, Thermoanaerobacterium aotearoense JW/SL-NZ611, Thermoanaerobacterium aotearoense JW/SL-NZ613 ${ }^{\mathrm{T}}$, Thermoanaerobacterium aotearoense JW/SL-NZ614, Thermoanaerobacterium aotearoense JW/SL-NZ625, Thermoanaerobacterium saccharolyticum B6A-RI ${ }^{\mathrm{T}}$, Thermoanaerobacterium thermosulfurigenes $4 \mathrm{~B}^{\mathrm{T}}$, Thermoanaerobacterium xylanolyticum $\mathrm{LX}-11^{\mathrm{T}}$, and molecular weight markers. $\mathrm{kD}$, kilodaltons. obacterium aotearoense and Thermoanaerobacterium thermosulfurigenes cells. In addition, the $\mathrm{pH}$ at which growth occurs ranges from around $\mathrm{pH} 3.8$ (Thermoanaerobacterium aotearoense) to higher than 8.5 (Thermoanaerobacterium thermosaccharolyticum).

Description of Thermoanaerobacterium aotearoense sp. nov. Thermoanaerobacterium aotearoense (ao.te.a'ro.en.se. Maori $\mathrm{n}$. ao cloud; Maori adj. tea, white; Maori adj. roa, long; N.L. adj. aotearoense, long white cloud, referring to the native Maori name for New Zealand, Aotearoa, Land of the Long White Cloud). The distribution of Thermoanaerobacteriumlike organisms in various volcanic heated environments on several continents has been surveyed, and strains belonging to Thermoanaerobacterium aotearoense have been isolated only from various hot springs in New Zealand. Therefore, the species is named to indicate the geographical region of the habitat, Aotearoa, the Maori name for New Zealand. The rod-shaped, Gram stain-negative but Gram type-positive cells are 2.1 to $14.3 \mu \mathrm{m}$ long and 0.7 to $1.0 \mu \mathrm{m}$ wide. The cells are peritrichously flagellated and exhibit tumbling motility. Oval-terminal spores are produced in lateexponential- to early-stationary-phase cultures. The organism is a moderately acidophilic thermophile that grows at 35 to $66^{\circ} \mathrm{C}$ (the optimum temperature is between 60 and $63^{\circ} \mathrm{C}$ ) and at $\mathrm{pH} 3.8$ to 6.8 (the optimum $\mathrm{pH}$ is $\mathrm{pH} 5.2$ ). The DNA base composition is 34.5 to $35 \mathrm{~mol} \% \mathrm{G}+\mathrm{C}$. Thiosulfate is converted to elemental sulfur which is deposited within the cytoplasm of the cells. The $16 \mathrm{~S}$ rRNA sequence is most similar to the sequences of other Thermoanaerobacterium species, from which the new species can be distinguished by differences in protein profiles (Fig. 7), $\mathrm{pH}$ and temperature ranges for growth, and substrate utilization patterns (Table 3).

Strain JW/SL-NZ613 ${ }^{\mathrm{T}}$ has a G+C content of $35 \mathrm{~mol} \%$ and is the type strain of Thermoanaerobacterium aotearoense; this strain has been deposited in the German Collection of Microorganisms as strain DSM 10170. The $\mathrm{pH}$ range for growth at $60^{\circ} \mathrm{C}$ is $\mathrm{pH} 3.8$ to 6.8 . At an initial $\mathrm{pH}$ of 5.2 , the temperature range for growth is about 35 to $66^{\circ} \mathrm{C}$. The cells are 0.7 to 0.9 $\mu \mathrm{m}$ wide and 2.1 to $10.7 \mu \mathrm{m}$ long.

TABLE 3. Properties that differentiate Thermoanaerobacterium aotearoense from other Thermoanaerobacterium species and "Thermoanaerobium lactoethylicum"

\begin{tabular}{|c|c|c|c|c|c|c|}
\hline Characteristic & $\begin{array}{c}\text { Thermoanaero- } \\
\text { bacterium } \\
\text { aotearoense }\end{array}$ & $\begin{array}{c}\text { Thermoanaero- } \\
\text { bacterium } \\
\text { saccharolyticum }^{a}\end{array}$ & $\begin{array}{c}\text { Thermoanaero- } \\
\text { bacterium } \\
\text { thermosulfurigenes }^{b}\end{array}$ & $\begin{array}{l}\text { Thermoanaero- } \\
\text { bacterium } \\
\text { xylanolyticum }^{a}\end{array}$ & $\begin{array}{c}\text { Thermoanaero- } \\
\text { bacterium } \\
\text { thermosaccharolyticum }^{c}\end{array}$ & $\begin{array}{l}\text { "Thermoanaerobium } \\
\text { lactoethylicum"d }\end{array}$ \\
\hline $\mathrm{G}+\mathrm{C}$ content $(\mathrm{mol} \%)$ & $34.5-35$ & 36 & 32.6 & 36.1 & $29-32$ & 34.6 \\
\hline $\mathrm{pH}$ range & $3.8-6.8$ & $5.0-7.5$ & $4.0-7.6$ & $5.0-7.5$ & $6.5-8.5$ & $5.0-8.5$ \\
\hline Optimum $\mathrm{pH}$ & 5.2 & 6 & $5.5-6.5$ & 6 & 7.8 & 7.0 \\
\hline Optimum temp $\left({ }^{\circ} \mathrm{C}\right)$ & $60.1-62.6$ & 60 & 60 & 60 & $55-60$ & 65 \\
\hline Maximum temp $\left({ }^{\circ} \mathrm{C}\right)$ & 65.7 & $68-70$ & 75 & 70 & 62 & 75 \\
\hline Spore formation & + & - & + & + & + & - \\
\hline \multicolumn{7}{|l|}{ Utilization of: } \\
\hline Arabinose & - & - & + & + & + & + \\
\hline Lactose & + & + & - & + & + & $\mathrm{NR}^{e}$ \\
\hline Xylan & + & + & + & + & + & - \\
\hline Mannitol & + & - & + & - & - & + \\
\hline Pectin & + & - & + & - & - & NR \\
\hline Pyruvate & - & - & - & + & - & - \\
\hline
\end{tabular}

${ }^{a}$ Data from reference 16.

${ }^{b}$ Data from references 16 and 27.

$c$ Data from reference 20 .

${ }^{d}$ Date from reference 13 .

${ }^{e} \mathrm{NR}$, not reported. 


\section{ACKNOWLEDGMENTS}

This work was supported initially by a grant to J.W. from NOVONordisk, Baeksvard, Denmark, and later by grant DE-FG05-93ER20127 from the U.S. Department of Energy and an equipment grant from the Georgia Research Alliance. The analysis of the S-layer was supported in part by a grant to P. Messner from the Austrian Science Foundation (project S7201-MOB) and the Austrian Ministry of Science, Research and Arts. We thank N. Weiss (Deutsche Sammlung von Mikroorganismen und Zellkulturen, Braunschweig, Germany) for the cell wall analysis, and P. Messner and A. Scheberl for the S-layer analysis. J.W. appreciates the great hospitality of Naomi Ward-Rainey, the Deutsche Sammlung von Mikroorganismen und Zellkulturen (Braunschweig, Germany), and Pat Morgan (Hamilton, New Zealand).

\section{REFERENCES}

1. Ausubel, F. M., R. Brent, R. E. Kingston, D. D. Moore, J. G. Seidman, J. A. Smith, and K. Struhl. 1989. Current protocols in molecular biology, p. 2.4.1-2.4.5. Wiley Interscience, New York.

2. Beuscher, N., F. Mayer, and G. Gottschalk. 1974. Citrate lyase from Rhodopseudomonas gelatinosa: purification, electron microscopy and subunit structure. Arch. Microbiol. 100:307-328.

3. Bonjour, F., and M. Aragno. 1984. Bacillus tusciae, a new species of thermoacidophilic, facultatively chemolithoautotrophic, hydrogen oxidizing sporeformer from a geothermal area. Arch. Microbiol. 139:397-401.

4. Bradford, M. M. 1976. A rapid and sensitive method for the quantitation of microgram quantities of protein utilizing the principle of protein-dye binding. Anal. Biochem. 72:248-254.

5. Burggraf, S., H. Fricke, A. Neuner, J. Kristjansson, P. Rouviere, L. Mandelco, C. R. Woese, and K. O. Stetter. 1990. Methanococcus igneus sp. nov, a novel hyperthermophilic methanogen from a shallow submarine hydrothermal system. Syst. Appl. Microbiol. 13:263-269.

6. Collins, M. D., P. A. Lawson, A. Willims, J. J. Cordoba, J. FernandezGarayzabal, P. Garcia, J. Cai, H. Hippe, and J. A. E. Farrow. 1994. The phylogeny of the genus Clostridium: proposal of five new genera and eleven new species combinations. Int. J. Syst. Bacteriol. 44:812-826.

7. De Soete, G. 1983. A least squares algorithm for fitting additive trees to proximity data. Psychometrika 48:621-626.

8. Dicks, L. M. T., H. J. J. van Vuuren, and F. Dellaglio. 1990. Taxonomy of Leuconostoc species, particularly Leuconostoc oenos, as revealed by numerical analysis of total soluble cell protein patterns, DNA base compositions, and DNA-DNA hybridization. Int. J. Syst. Bacteriol. 40:83-91.

9. Egelseer, E., I. Schocher, M. Sára, and U. B. Sleytr. 1995. The S-layer from Bacillus stearothermophilus DSM 2358 functions as an adhesion site for a high-molecular-weight amylase. J. Bacteriol. 177:1444-1451.

10. Freier, D., C. P. Mothershed, and J. Wiegel. 1988. Characterization of Clos tridium thermocellum JW-20. Appl. Environ. Microbiol. 54:204-211.

11. Jones, W. J., J. A. Leigh, F. Mayer, C. R. Woese, and R. S. Wolfe. 1983. Methanococcus jannaschii sp. nov., an extremely thermophilic methanogen from submarine hydrothermal vent. Arch. Microbiol. 136:254-261.

12. Jukes, T. H., and C. R. Cantor. 1969. Evolution of protein molecules, p 21-132. In H. N. Munro (ed.), Mammalian protein metabolism. Academic Press, Inc., New York.

13. Kondratieva, E. N., E. V. Zacharova, V. I. Duda, and V. V. Krivenko. 1989 Thermoanaerobium lactoethylicum spec. nov., a new anaerobic bacterium from a hot spring of Kamchatka. Arch. Microbiol. 151:117-122.

14. Laemmli, U. K. 1970 . Cleavage of structure proteins during the assembly of the head of bacteriophage T4. Nature (London) 227:680-685.

15. Lauerer, G., J. K. Kristjansson, T. A. Langworthy, H. König, and K. O. Stetter. 1986. Methanothermus sociabilis sp. nov., a second species within the Methanothermaceae growing at $97^{\circ} \mathrm{C}$. Syst. Appl. Microbiol. 8:100-105.

16. Lee, Y.-E., M. K. Jain, C. Lee, S. E. Lowe, and J. G. Zeikus. 1993. Taxonomic distinction of saccharolytic thermophilic anaerobes: description of Thermoanaerobacterium xylanolyticum gen. nov., sp. nov., and Thermoanaerobacterium saccharolyticum gen. nov., sp. nov.; reclassification of Thermoanaerobium brockii, Clostridium thermosulfurogenes and Clostridium thermohydrosulfuricum E100-69 as Thermoanaerobacter brockii comb. nov., Thermoanaerobacterium thermosulfurigenes comb. nov., and Thermoanaerobacter thermohydrosulfuricum comb. nov., respectively; and transfer of Clostridium thermohydrosulfuricum $39 \mathrm{E}$ to Thermoanaerobacter ethanolicus. Int. J. Syst. Bacteriol. 43:41-51.

17. Leigh, J. A., F. Mayer, and R. S. Wolfe. 1981. Acetogenium kivui, a new thermophilic hydrogen-oxidizing, acetogenic bacterium. Arch. Microbiol 129:275-280.

18. Li, Y., L. Mandelco, and J. Wiegel. 1993. Isolation and characterization of a moderately thermophilic alkaliphile, Clostridium paradoxum sp. nov. Int. J. Syst. Bacteriol. 43:450-460.

19. Lowe, S. E., M. K. Jain, and J. G. Zeikus. 1993. Biology, ecology, and biotechnological applications of anaerobic bacteria adapted to environmental stresses in temperature, $\mathrm{pH}$, salinity, and substrates. Microbiol. Rev. 57: 451-509.

20. McClung, L. S. 1935. Studies on anaerobic bacteria. IV. Taxonomy of cultures of a thermophilic species causing "swells" of canned food. J. Bacteriol. 29:189-203.

21. Mesbah, M., U. Premachandran, and W. B. Whitman. 1989. Precise measurement of the $\mathrm{G}+\mathrm{C}$ content of deoxyribonucleic acid by high-performance liquid chromatography. Int. J. Syst. Bacteriol. 39:159-167.

22. Messner, P., F. Hollaus, and U. B. Sleytr. 1984. Paracrystalline cell wall surface layers of different Bacillus stearothermophilus strains. Int. J. Syst. Bacteriol. 34:202-210.

23. Messner, P., and U. B. Sleytr. 1992. Crystalline bacterial cell-surface layers. Adv. Microb. Physiol. 33:213-275.

24. Pley, U., J. Schipka, A. Gambacorta, H. W. Jannasch, H. Fricke, R. Rachel, and K. O. Stetter. 1991. Pyrodictium abyssi sp. nov. represents a novel heterotrophic marine archaeal hyperthermophile growing at $110^{\circ} \mathrm{C}$. Syst. Appl. Microbiol. 14:245-253.

25. Rainey, F. A., M. Dorsch, H. W. Morgan, and E. Stackebrandt. 1992. 16S rDNA analysis of Spirochaeta thermophila: its phylogenetic position and implications for the systematics of the order Spirochaetales. Syst. Appl. Microbiol. 15:197-202.

26. Rainey, F. A., N. L. Ward, H. W. Morgan, R. Toalster, and E. Stackebrandt. 1993. Phylogenetic analysis of anaerobic thermophilic bacteria: aid for their reclassification. J. Bacteriol. 175:4772-4779.

27. Schink, B., and J. G. Zeikus. 1983. Clostridium thermosulfurogenes sp. nov., a new thermophile that produces elemental sulphur from thiosulphate. J. Gen. Microbiol. 129:1149-1158.

28. Schleifer, K.-H., and O. Kandler. 1972. Peptidoglycan types of bacterial cell walls and their taxonomic implications. Bacteriol. Rev. 36:407-477.

29. Segerer, A. H., A. Trincone, M. Gahrtz, and K. O. Stetter. 1991. Stygiolobus azoricus gen. nov., sp. nov. represents a novel genus of anaerobic, extremely thermoacidophilic archaebacteria of the order Sulfolobales. Int. J. Syst. Bacteriol. 41:495-501.

30. Sharp, R. J., and M. J. Monster. 1986. Biotechnological implications for microorganisms from extreme environments, p. 215-295. In R. A. Herbert and G. A. Codd (ed.), Microbes in extreme environments. Academic Press, London.

31. Sleytr, U. B., P. Messner, and D. Pum. 1988. Analysis of crystalline bacterial surface layers by freeze-etching, metal shadowing, negative staining and ultrathin sectioning. Methods Microbiol. 20:29-60.

32. Soh, A. L. A., H. Ralambotiana, B. Ollivier, G. Prensier, E. Tine, and J. L. Garcia. 1991. Clostridium thermopalmarium sp. nov., a moderately thermophilic butyrate-producing bacterium isolated from palm wine in Senegal. Syst. Appl. Microbiol. 14:135-139.

33. Spurr, A. R. 1969. A low-viscosity epoxy resin embedding medium for electron microscopy. J. Ultrastruct. Res. 26:31-43.

34. Stetter, K. O. 1993. Life at the upper temperature border, p. 195-219. In J. Tran Thanh Van, K. Tran Thanh Van, J. C. Mounolon, J. Schneider, and C. McKay (ed.), Frontiers of life. Editions Frontières, Gif-sur-Yvette, France.

35. Valentine, R. C., B. M. Shapiro, and E. R. Stadtman. 1968. Regulation of glutamine synthetase. XII. Electron microscopy of the enzyme from E. coli. Biochemistry 7:2143-2152

36. Whitman, W. B., S. Sohn, D. S. Caras, and U. Premachandran. 1986. Isolation and characterization of 22 mesophilic methanococci. Syst. Appl. Microbiol. 7:235-240.

37. Wiegel, J. 1981. Distinction between the Gram reaction and the Gram type of bacteria. Int. J. Syst. Bacteriol. 31:88.

38. Wiegel, J., M. Braun, and G. Gottschalk. 1981. Clostridium thermoautotrophicum species novum, a thermophile producing acetate from molecular hydrogen and carbon dioxide. Curr. Microbiol. 5:255-260.

39. Wiegel, J., L. G. Ljungdahl, and J. R. Rawson. 1979. Isolation from soil and properties of the extreme thermophile Clostridium thermohydrosulfuricum. J. Bacteriol. 139:800-810.

40. Wiegel, J., and L. Quandt. 1982. Determination of the Gram type using the reaction between polymyxin $\mathrm{B}$ and lipopolysaccharides of the outer cell wall of whole bacteria. J. Gen. Microbiol. 128:2261-2270.

41. Wisotzkey, J. D., P. Jurtshuk, Jr., G. E. Fox, G. Deinhard, and K. Poralla. 1992. Comparative sequence analyses on the 16S rRNA (rDNA) of Bacillus acidocaldarius, Bacillus acidoterrestris, and Bacillus cycloheptanicus and proposal for creation of a new genus, Alicyclobacillus gen. nov. Int. J. Syst. Bacteriol. 42:263-269.

42. Zillig, W., A. Gierl, G. Schreiber, S. Wunderl, D. Janekovic, K. O. Stetter, and H. P. Klenk. 1983. The archaebacterium Thermofilum pendens represents a novel genus of the thermophilic, anaerobic sulfur respiring Thermoproteales. Syst. Appl. Microbiol. 4:79-87.

43. Zillig, W., K. O. Stetter, W. Schäfer, D. Janekovic, S. Wunderl, I. Holz, and P. Palm. 1981. Thermoproteales: a novel type of extremely thermoacidophilic anaerobic archaebacteria isolated from Icelandic solfataras. Zentralbl. Bakteriol. Parasitenkd. Infektionskr. Hyg. Abt. 1 Orig. Reihe C 2:205-227. 